\section{INTERACTION OF BLEOMYCIN WITH NUCLEIC ACIDS AS PROBED BY ESR SPECTROMETRY OF IRON(II)-NITROSYL COMPLEX OF BLEOMYCIN}

Sir :

Bleomycin (BLM) causes DNA strand scission in the presence of $\mathrm{Fe}(\mathrm{II})$ ion and molecular oxygen $^{1)}$. Cleavage of cellular DNA by BLM probably accounts for the antitumor activity of this drug. Fluorescence quenching study has demonstrated that (1) the bithiazole portion of BLM preferentially binds to guanine base in nucleic acids and (2) the positive charge at the terminal amine enhances BLM binding to nucleic acids ${ }^{2}$. However, the bindings of these groups to DNA as seen by the quenching effects are not sufficient to interprete the BLM-DNA reaction because BLM binds to RNA as well as to $\mathrm{DNA}^{2)}$, although BLM does not cleave $\mathrm{RNA}^{3)}$. The electron spin resonance (ESR) studies have shown that the BLM-Fe(II)-NO complex is conformationally perturbed in the presence of calf thymus $\mathrm{DNA}^{4,5)}$. This paper deals with the interaction of the $\mathrm{Fe}(\mathrm{II})-\mathrm{NO}$ complex of BLM with DNA, denatured DNA, ribohomopolymers and RNA.

BLM-A2, BLM-B2, iso BLM-A2 ${ }^{6)}$, and depyruvamide (dep) BLM-A2 ${ }^{7}$ were used in this experiment. Calf thymus DNA, bakers yeast RNA, polyguanylic acid (poly G), and polyuridylic acid (poly U) were purchased from P-L Biochemicals. The hyperchromicity of heatdenatured DNA used in this study was $30 \%$. In the presence or absence of nucleic acid, the $\mathrm{Fe}(\mathrm{II})$-NO complex of BLM was prepared by addition of a few milligrams of $\mathrm{Na}^{14} \mathrm{NO}_{2}$ and sodium dithionite to the $1: 1 \mathrm{BLM}-\mathrm{Fe}(\mathrm{II}) \mathrm{com}-$ plex solution at $\mathrm{pH} 6.9$ according to the previous procedure ${ }^{4)}$. ESR spectrum was measured at the concentration of $0.2 \mathrm{~mm}$ BLM-Fe(II)-NO complex in the presence of $2 \sim 10 \mathrm{mg} / \mathrm{ml}$ nucleic acids. X-Band ESR spectrum was recorded using a JES-FE-3X spectrometer.

Fig. 1 (A) shows the ESR spectrum of BLMA2-Fe(II)-NO complex. This ESR feature exhibits rhombic symmetry with a triplet nitrogenhyperfine interaction in the central $\mathrm{g}_{z}$ signal, which is typical of six-coordinated type. We interpreted that the three-line $\mathrm{N}$-splittings on $\mathrm{g}_{\text {mid }}$ are due to the strong NO-to-iron bonding with the concomitantly weakened fifth axial ligand-
Fig. 1. ESR Spectra of BLM-A2-Fe(II)-NO (A), BLM-A2-Fe(II)-NO + DNA (B), BLM-A2-Fe(II)$\mathrm{NO}+$ denatured DNA (C), and BLM-A2-Fe(II)$\mathrm{NO}+\mathrm{RNA}(\mathrm{D})$ at $77 \mathrm{~K}$.

(A)

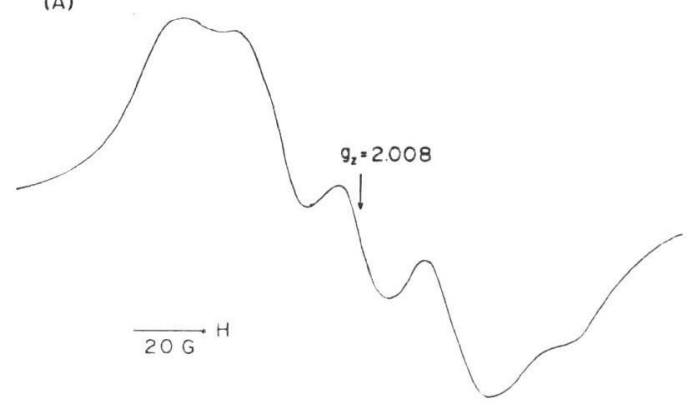

(B)

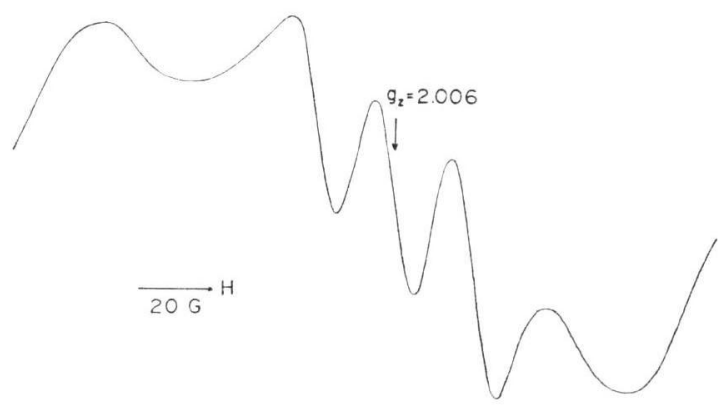

(C)
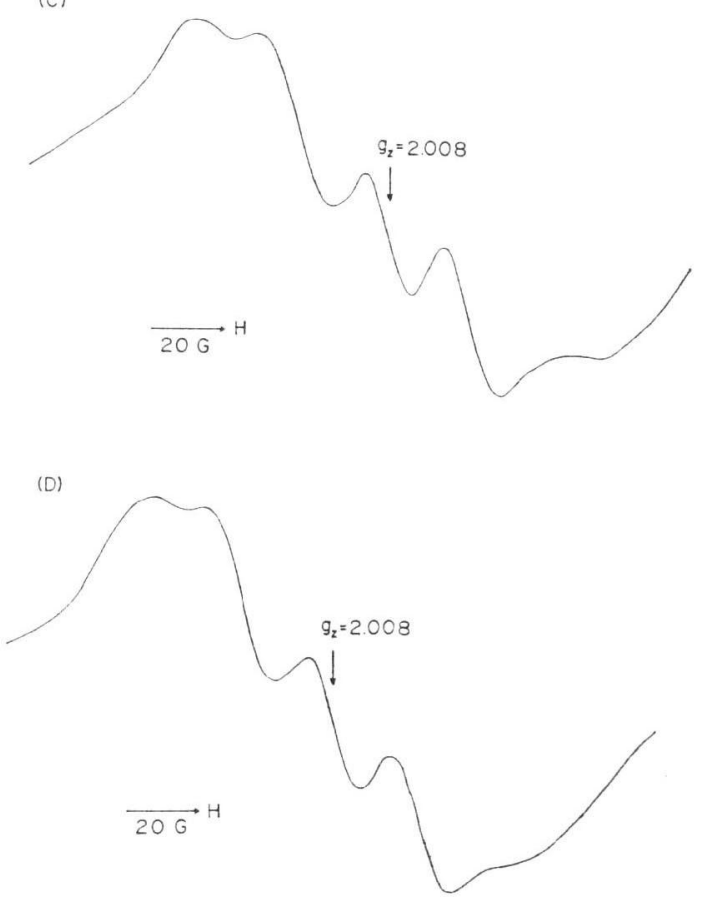
Table 1. ESR Parameters for iron(II)-nitrosyl complex of bleomycin in the presence or absence of nucleic acid.

\begin{tabular}{l|c|c|c|c|c}
\multicolumn{1}{c|}{ Complex } & $\mathrm{g}_{\mathrm{x}}$ & $\mathrm{g}_{\mathrm{z}}$ & $\mathrm{g}_{\mathrm{y}}$ & $\mathrm{A}^{\mathrm{N}}, \mathrm{G}$ & $\mathrm{N}-\mathrm{hfs}$ (line) \\
\hline BLM-A2-Fe(II)-NO & 2.041 & 2.008 & 1.976 & 23.6 & 3 \\
BLM-B2-Fe(II)-NO & 2.041 & 2.008 & 1.976 & 23.6 & 3 \\
iso BLM-A2-Fe(II)-NO & 2.040 & 2.008 & 1.976 & 23.6 & 3 \\
dep BLM-A2-Fe(II)-NO & 2.052 & 1.999 & 2.016 & 17.5 & 3 \\
BLM-A2-Fe(II)-NO+DNA & 2.060 & 2.006 & 1.962 & 24.0 & 3 \\
BLM-A2-Fe(II)-NO+denatured DNA & 2.045 & 2.008 & 1.971 & 23.9 & 3 \\
BLM-A2-Fe(II)-NO+poly G & 2.043 & 2.008 & 1.973 & 23.6 & 3 \\
BLM-A2-Fe(II)-NO+poly U & 2.041 & 2.008 & 1.976 & 23.6 & 3 \\
BLM-A2-Fe(II)-NO+RNA & 2.041 & 2.008 & 1.976 & 23.6 & 3 \\
\hline
\end{tabular}

to-iron bonding ${ }^{4}$. BLM-B2-Fe(II)-NO and iso BLM-A2-Fe(II)-NO give the same ESR parameters as those of BLM-A2 (see Table 1). While the Fe(II)-NO complex of dep BLM-A2 which lacks the fifth axial amino nitrogen gives an ESR spectrum characteristic to the five-coordinated type (three-line $\mathrm{N}$-splittings on $\left.\mathrm{g}_{\min }\right)^{8)}$.

Fig. 1 also shows the ESR spectra of the BLMA2- $\mathrm{Fe}(\mathrm{II})-{ }^{14} \mathrm{NO}$ complex in the presence of DNA (B), denatured DNA (C), and RNA (D). Table 1 summarizes the effect of several nucleic acids on the ESR parameters of the $\mathrm{Fe}(\mathrm{II})$ - NO complex of BLM-A2. Of special interest is the remarkable difference between DNA and RNA. DNA induced a large shift of the $\mathrm{g}_{x}$ and $\mathrm{g}_{\mathrm{y}}$ values which were attributed to the in-plane anisotropy in the iron site. In contrast, RNA did not entirely affect the original ESR parameters. In addition, the effects of denatured DNA and poly G were significantly smaller than that of DNA. On the other hand, the fluorescence study has indicated that (1) BLM shows stronger interaction with heat-denatured calf thymus DNA (quenching, 65\%) and poly G $(77 \%)$ rather than with the intact double-strand DNA (56\%) and (2) among ribohomopolymers the interaction decreases in the order of poly $\mathrm{G}>$ poly A $(39 \%)>$ poly $\mathrm{U} \quad(14 \%)>$ poly $\mathrm{C}$ $(0 \%){ }^{2)}$ These results indicate that there is no apparent correlation between the extent of the BLM-nucleic acid interaction measured by fluorescence quenching and the structural alteration of the BLM-Fe(II)-NO complex in the presence of nucleic acids detected by ESR spectroscopy. The apparently different BLM-nucleic acid interaction observed by the two methods can be reasonably explained by the fact that the fluo- rescence quenching is the probe for the binding site of BLM to DNA while the ESR is the probe for the reaction site of BLM with DNA causing the DNA fragmentation. The binding site of BLM is the bithiazole-terminal amine portion and the reaction site is the $\beta$-aminoalanine-pyrimidine- $\beta$-hydroxyhistidine portion which is involved in the $\mathrm{Fe}$ (II)-complex formation ${ }^{2,8,9)}$.

In conclusion, the conformation of the BLM$\mathrm{Fe}(\mathrm{II})-\mathrm{NO}$ complex is not perturbed with RNA in contrast with DNA, although BLM can bind to RNA as well as to DNA. This will be an account for the selective strand scission of DNA but not of RNA by BLM.

\section{Yukio SugIURA \\ *TOMOHISA TAKITA \\ *Hamao Umezawa}

Faculty of Pharmaceutical Sciences Kyoto University, Kyoto 606, Japan

*Institute of Microbial Chemistry

Kamiosaki, Shinagawa-ku, Tokyo 141, Japan

(Received October 15, 1980)

\section{References}

1) Sausville, E. A.; R. W. Stein, J. Peisach \& S. B. Horwitz: Properties and products of the degradation of DNA by bleomycin and iron (II). Biochemistry 17: 2746 2754, 1978

2) Kasai, H.; H. Naganawa, T. Takita \& $\mathbf{H}$. UMEZawa: Chemistry of bleomycin. XXII. Interaction of bleomycin with nucleic acids, preferential binding to guanine base and electrostatic effect of the terminal amine. J. Antibiotics 31: 1316 1320, 1978 
3) Suzuki, H.; K. Nagai, E. Akutsu, H. Yamaki, N. TANAKA \& H. UMEZAWA: On the mechanism of action of bleomycin. Strand scission of DNA caused by bleomycin and its binding to DNA in vitro. J. Antibiotics 23: $473 \sim 480$, 1970

4) Sugiura, Y. \& K. Ishizu: Metallobleomycins. Electron spin resonance study on nitrosyl complex of iron(II)-bleomycin. J. Inorg. Biochem. 11: $171 \sim 180,1979$

5) Antholine, W. E. \& D. H. Petering: Reaction of FeBlm with DNA. Fe(II)Blm-NO. Biochem. Biophys. Res. Commun. 91 : $529 \sim 533$, 1979

6) Nakayama, Y.; M. Kunishima, S. ОмOto, T. TAKITA \& H. UMEZAWA: Chemistry of bleomycin. XII. Iso-bleomycin A2, a product of carbamoyl group migration. J. Antibiotics 26: $400 \sim 401,1973$

7) Naganawa, H.; Y. Muraoka, T. Takita \& H. UMEZAWA: Chemistry of bleomycin. XVIII. Carbon-13 NMR studies. J. Antibiotics 30: 388 396, 1977

8) Sugiura, Y.: Bleomycin-iron complexes. Electron spin resonance study, ligand effect, and implication for action mechanism. J. Am. Chem. Soc. 102: 5208 5215, 1980

9) Takita, T.; Y. Muraoka, T. Nakatani, A. FujII, Y. IItAKa \& H. Umezawa: Chemistry of bleomycin. XXI. Metal-complex of bleomycin and its implication for the mechanism of bleomycin action. J. Antibiotics 31: 1073 1077, 1978 